\title{
Внутрицентровая релаксация мелких доноров сурьмы в деформированном германии
}

\author{
Цыпленков В.В, Шастин В.Н.
}

ИФМ РАН, 603087, Нижегородская обл., Кстовский район, д. Афонино, ул. Академическая, 7

DOI 10.34077/Semicond2019-66

В настоящее время научная активность многих исследовательских групп направлена на изучение квантовых оптически управляемых когерентных состояний различных систем и создания на их основе принципиально новых полупроводниковых устройств, сопряженных с развитой кремниевой и германиевой технологией. Одними из кандидатов рассматриваются кулоновские центры в полупроводниках. В этом контексте вычисление релаксационных темпов возбужденных состояний примесных центров в германии является важной задачей, т.к. в конечном счете, они определяют предельно достижимые времена жизни оптически возбуждаемых когерентных суперпозиций электронных состояний примеси. Данная работа посвящена вычислению темпов распада возбужденных состояний доноров сурьмы в кристалле германия при взаимодействии с длинноволновыми акустическими фононами. Рассмотрено влияние на темпы одноосной деформации сжатия в кристаллографическом направлении [111].

Расчеты выполнены в рамках метода эффективных масс. Использованы водородоподобные волновые функции, учитывающие анизотропию эффективной массы зоны проводимости германия. Расчеты выполнены в приближении изотропного закона дисперсии фононов. Для продольных акустических фононов значение средней групповой скорости было выбрано $5 \times 10^{5} \mathrm{~cm} / \mathrm{c}$, для поперечных - $3.3 \times 10^{5} \mathrm{~cm} / \mathrm{c}$. Рассматривалось только внутридолинные переходы, влиянием междолинных процессов электрон-фононного взаимодействия пренебрегалось. В таблице 1 представлены вычисленные темпы переходов между состояниями донора сурьмы в недеформированном кристалле германия.

Таблица 1 - Темпы переходов в единицах $10^{9} c^{-1}$ при излучении продольных $P_{l}$ и поперечных $P_{t}$ акустических фононов. Прочерками отмечены пренебрежимо малые темпы.

\begin{tabular}{|c|c|c|c|c|c|}
\hline Переход & $P_{l}$ & $P_{t}$ & Переход & $P_{l}$ & $P_{t}$ \\
\hline $3 p_{ \pm}-2 p_{0}$ & 0.012 & - & $4 p_{0}-3 p_{0}$ & 0.71 & 0.031 \\
\hline $3 p_{ \pm}-2 p_{(+)}$ & 0.57 & 0.34 & $4 p_{0}-3 s$ & 0.032 & 0.008 \\
\hline $3 p_{ \pm}-2 p_{(-)}$ & 0.85 & 0.08 & $4 p_{0}-2 s$ & 0.19 & 0.1 \\
\hline $3 p_{ \pm}-4 p_{0}$ & 0.12 & 0.12 & $4 p_{0}-2 p_{0}$ & 0.057 & - \\
\hline $3 p_{ \pm}-3 p_{0}$ & 1.3 & 0.093 & $2 p_{ \pm}-3 p_{0}$ & 1.3 & 1.3 \\
\hline $3 p_{ \pm}-3 s$ & 0.038 & 0.062 & $2 p_{ \pm}-2 p_{0}$ & - & - \\
\hline $3 p_{ \pm}-2 s$ & 0.04 & 0.003 & $2 p_{ \pm}-2 s$ & 0.13 & \\
\hline $3 p_{ \pm}-1 s$ & - & - & $2 s-2 p_{0}$ & 0.4 & - \\
\hline $3 p_{0}-2 s$ & 1.5 & - & $2 s-1 s$ & 1.5 & - \\
\hline $3 p_{0}-2 p_{0}$ & 4.43 & - & $2 s-1 s$ & 0.4 & - \\
\hline $2 p_{0}-1 s$ & 2.8 & - & $2 p_{0}-1 s$ & 2.3 & - \\
\hline
\end{tabular}

Одноосная деформация согласно расчетам не изменяет полного темпа распада состояний доноров, что связано со спецификой энергетического спектра донора сурьмы в германии. Сравнение результатов расчетов с экспериментальными данными по измерению релаксационных времен $[1,2]$ показывают одинаковый порядок величин темпов распада состояний.

Исследование выполнено в ИФМ РАН за счет гранта РНФ (проект № 19-72-20163).

[1] Р. Х. Жукавин et al., Письма в ЖЭТФ, 106, 555 (2017).

[2] Е.М. Гершензон, Г.Н. Гольиман, Л.А. Орлов, Н.Г., Письма в ЖЭТФ, 25, 574 (1977). 